\title{
Decay Resistance of Particleboards Manufactured with Four Agro-Forest Residues Using Cassava Starch and Urea Formaldehyde as Adhesives
}

\author{
Prosper Mensah ${ }^{1}$, Stephen Jobson Mitchual2 ${ }^{*}$, Mary Mamle Apetorgbor ${ }^{1}$, \\ Kwasi Frimpong-Mensah ${ }^{3}$ \\ ${ }^{1}$ CSIR-Forestry Research Institute of Ghana, KNUST, Kumasi, Ghana \\ ${ }^{2}$ Department of Construction and Wood Technology Education, University of Education, Winneba, Kumasi Campus, Kumasi, \\ Ghana \\ ${ }^{3}$ Department of Wood Science and Technology, Kwame Nkrumah University of Science and Technology, Kumasi, Ghana \\ Email: *stephenjobsonmitchual@gmail.com
}

How to cite this paper: Mensah, P., Mitchual, S.J., Apetorgbor, M.M. and Frimpong-Mensah, K. (2020) Decay Resistance of Particleboards Manufactured with Four Agro-Forest Residues Using Cassava Starch and Urea Formaldehyde as Adhesives. Journal of Agricultural Chemistry and Environment, 9, 240-254.

https://doi.org/10.4236/jacen.2020.94019

Received: June 1, 2020

Accepted: November 1, 2020

Published: November 4, 2020

Copyright $\odot 2020$ by author(s) and Scientific Research Publishing Inc. This work is licensed under the Creative Commons Attribution International License (CC BY 4.0).

http://creativecommons.org/licenses/by/4.0/

\begin{abstract}
Many factors including depletion of the forest, environmental awareness, and generation of large quantities of agro-forest residues have increased the need to partially or wholly replace wood with agro-forest residue for particleboard production. This study assessed the decay resistance of particleboards produced from four agro-forest residues using cassava starch and urea formaldehyde as adhesives. Musa paradisiaca pseudostem, Theobroma cacao stem and pod, and sawdust of Ceiba pentandra were used for the study. Properties determined were: Weight loss, decay resistance rating and decay susceptibility index. These properties were evaluated after 12 weeks of exposure to Coriolopsis polyzona in accordance with ASTM D 2017-05. The results indicate that the weight loss for Musa paradisiaca pseudostem particleboard was least for both urea formaldehyde and cassava starch adhesives. Even though almost all the particleboards produced were classified as resistant or highly resistant to fungi attack, those produced with urea formaldehyde had better decay resistance properties than that of cassava starch. Furthermore, particleboards coated with synthetic polyvinyl lacquer had better resistance to fungi attack than the uncoated ones. At 5\% level of significance, the agro-forest residue, adhesive and surface finish as well as their interactions had significant effects on decay resistance of the particleboards produced. It is recommended that further studies which aim at determining the effect of combination of the agro-forest residues and that of urea formaldehyde and cassava starch be conducted to determine their effects on decay properties of particleboards.
\end{abstract}




\section{Keywords}

Agro-Forest Residue, Cassava Starch, Decay Resistance, Particleboard, Urea Formaldehyde

\section{Introduction}

Particleboard is manufactured by hot compression of wood particles, blended with binding agent and forming the mixture into a sheet. The demand for particleboard products has increased substantially throughout the world, representing $57 \%$ of the total consumption of wood-based panels, a percentage that is continuously growing at a rate of $2 \%-5 \%$ annually [1] [2]. Sawdust from timber processing industry has been the main source of raw material for this product. However, due to the depletion of the forest, this source could not be sustained [3].

Particleboards can be produced from any agro-forestry residues, as long as they have required physical, mechanical and biological resistance. The quality of the final product is directly related to the choice of the raw material [4]. Consequently, there have been a lot of studies on the suitability of the available lignocellulose materials in the production of particleboard. Some of these are oat hulls, corn stalk, elephant grass, canola straws, rice husk, sugarcane bagasse and corn cob [3] [5] [6] [7] [8]. There is the need to extend such studies to cover other lignocellulosic agricultural residues such as Musa paradisiaca pseudostem, Theobroma cacao stem (without the bark) and pod, and sawdust of Ceiba pentandra.

Musa paradisiaca pseudostem is a lignocellulosic agricultural residue which is readily available in large quantities on farmlands and has no special industrial application. Globally, the production of Musa paradisiaca grew at a compound annual rate of 3.7 percent, reaching a record of 117.9 million tonnes in 2015 from around 68.2 million tonnes in 2000 [9]. Ghana is the largest producer of Musa paradisiaca in West Africa and second in Africa [10] as cited in [11]. Studies indicate that at the end of the year 2016, about 7,184,842 tonnes of M. paradisiaca pseudostem residue were generated in Ghana [9]. This constitutes about $59 \%$ of the total agricultural crop residues generated. Therefore, a large amount of Musa paradisiaca pseudostem residue is generated annually in Ghana.

When Theobroma cacao plants are waned, the trees are felled for firewood because the stems are not large enough to produce lumber. In 2018, Ghana cut down 680,000 hectares of over-aged cocoa trees, representing 40 percent of the country's stock of cocoa trees [12]. These trees do not have any significant industrial application apart from being used as household fuel wood. However, particleboards can be made with lower grade plant materials than other wood composite panels such as oriented strand board and plywood. Thus, all plant materials can essentially be utilized for making particleboard. In addition, the cultivation and processing of Theobroma cacao generate a large amount of co- 
coa pods as residue which are either burnt on the farms causing environmental pollution or inefficiently used as fuel for cooking. The Theobroma cacao pod represents $70 \%$ to $75 \%$ of the whole cocoa fruit weight. Therefore, each ton of cocoa fruit will produce between 0.70 to 0.75 tonnes of cocoa pod [13]. Ghana and Cote d'lvoire produced 900,000 and 2,000,000 tonnes of cocoa respectively in 2018 [14]. Therefore, an estimated amount of 2,175,000 tonnes of waste cocoa pod was generated in 2018 .

Lastly, wood residue in the form of sawdust which is generated in large quantities from processing round logs remain unutilized. About $10 \%-13 \%$ of the total volume of the wood log is reduced to sawdust in milling operations [15]. One of the most frequently processed timber species in Ghana wood industries is Ceiba pentandra. Ceiba pentandra is a low-density species $\left(409.22 \mathrm{~kg} / \mathrm{m}^{3}\right)$ with acid-insoluble lignin and alpha-cellulose contents of $24.34 \%$ and $41.24 \%$ respectively [16]. The low particle density of Ceiba pentandra makes it most suitable for densified biomass products such as manufactured boards. This is because particles of Ceiba pentandra with low particle density would have higher tendency of undergoing plastic deformation at low compacting pressure leading to the formation of strong bonds.

This paper is part of a wider study conducted to characterize particleboard produced from selected agro-forest residues. Specifically, the paper reports the findings of decay resistance properties of particleboards produced from Musa paradisiaca pseudostem, Theobroma cacao stem and pod, and sawdust of Ceiba pentandra residues using cassava starch and urea formaldehyde.

\section{Methodology}

\subsection{Particleboard Manufacture}

Musa paradisiaca pseudostem, Theobroma cacao stem (without the bark) and pod, and sawdust of Ceiba pentandra were used for the study. The Musa paradisiaca pseudostem was obtained from a commercial farm land after harvesting. The water was extracted, and the fibres oven-dried before milling. Theobroma cacao trees of twenty-five years were felled and converted into sawdust by sawing. Fresh Theobroma cacao pods were first sun-dried and then crushed into particles using a hammer mill. Sawdust of Ceiba pentandra was obtained from a timber processing company in Ghana. The four biomass materials were sun dried at an average relative humidity and temperature of $70 \%$ and $29^{\circ} \mathrm{C}$ respectively for three weeks within the months of March and April. Thereafter, the materials were further dried to moisture content ranging from $3 \%$ to $6 \%$ using a solar dryer. The agro-forest raw materials were then classified and particle size (PS) $0.5 \mathrm{~mm} \leq$ PS $<1.5 \mathrm{~mm}$ were blended with cassava starch (CS) and urea formaldehyde (UF) and formed mat with it. Ammonium chloride $\left(\mathrm{NH}_{4} \mathrm{Cl}\right)$ was added as a curing catalyst based on the solid content of the adhesive.

The resinated particles were pre-pressed into $80 \mathrm{~mm}$ thick single layer of 300 $\mathrm{mm} \times 300 \mathrm{~mm}$ aluminium sheet mould. Metal stops of dimension $20 \mathrm{~mm} \times 20$ 
$\mathrm{mm}$ were used in the press platens to allow the same particle thickness to be achieved for the entire test run. The mat was pressed with the following pressing conditions: Pressing temperature $170^{\circ} \mathrm{C}$; Pressing pressure 3.5 MPa; Pressing time 8 minutes; Pressing closing rate $3-4 \mathrm{~mm} /$ minute; Target thickness $20 \mathrm{~mm}$; Target density $500-600 \mathrm{~kg} / \mathrm{m}^{3}$; Hardener 2\%; Adhesive (UF and CS) and Compacting time 15 minutes. The produced particleboards were then trimmed and conditioned in a control room with a temperature of $20^{\circ} \mathrm{C} \pm 2{ }^{\circ} \mathrm{C}$ and a relative humidity of $62 \% \pm 2 \%$ for 6 days before they were sawn into various sizes for further testing. Each type of particleboard was replicated five (5) times.

\subsection{Preparation of Test Specimen}

Two types of specimens of the particleboards produced were prepared for the study-the polished specimen and the unpolished specimen (Figure 1). The particleboards were planed to a thickness of $14 \mathrm{~mm}$ using a tungsten carbide tipped three-cutter block thicknesser planer with a cutting speed of $4000 \mathrm{rpm}$. Thereafter, sanding machine (Model number Bosch GSS20-40) with abrasive grit of 180 was used to smoothen the surface of the planed samples.

With the polished specimen, three layers of clear synthetic polyvinyl lacquer (SPL) were applied to the sanded surface using a hand brush at an environmental temperature of $32^{\circ} \mathrm{C}$ and relative humidity of $78 \%$. After each application, four hours were allowed for the drying of the previous one. In accordance with ASTM D 2017-05 standard [17], the samples were sawn into specimens of dimension 14

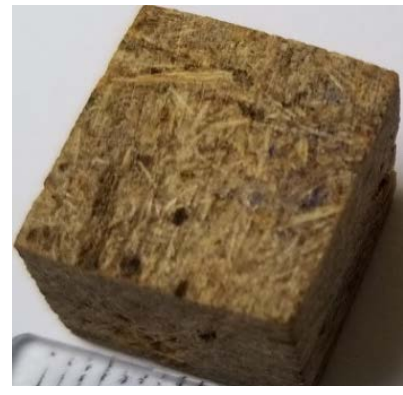

(a)

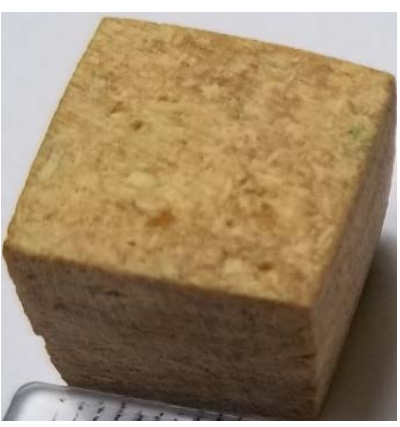

(c)

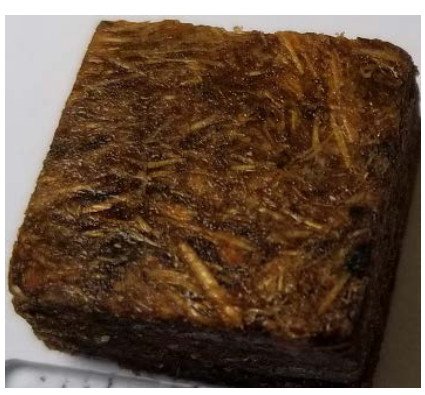

(b)

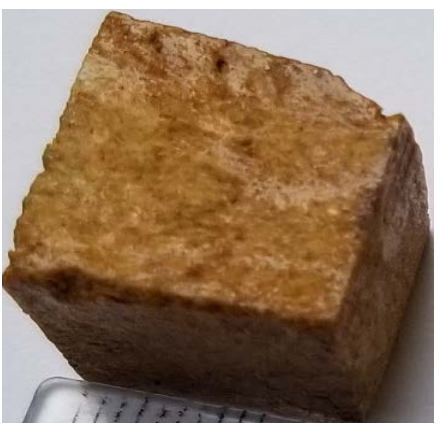

(d)

Figure 1. Polished and unpolished particleboard specimens. (a) Unpolished Musa paradisiaca pseudostem specimen; (b) Polished Musa paradisiaca pseudostem specimen; (c) Unpolished Ceiba pentandra specimen; (d) Polished Ceiba pentandra specimen. 
$\mathrm{mm} \times 14 \mathrm{~mm} \times 14 \mathrm{~mm}$ using a fine teeth dovetail saw. Triplochiton scleroxylon of dimension $15 \mathrm{~mm} \times 50 \mathrm{~mm} \times 300 \mathrm{~mm}$ was used as substrates.

\subsection{Decay Resistance Test of Specimen}

The decay resistance test of the specimens was conducted using simple accelerated laboratory (soil block) method in accordance with ASTM D 2017-05 [17]. French square bottles, three-quarter filled with moistened screened top soil were used as decay chamber. The soil had $\mathrm{pH}$ of 6.2 and moisture holding capacity of 39\%. Seventy-two strips of Triplochiton scleroxylon were immersed in distilled water for 24 hours and placed on top of the soils in the glass jars. The glass jars were loosely closed with their plastic screw-lids and sterilized in an autoclave at a temperature of $121^{\circ} \mathrm{C}$ with a pressure of $15 \mathrm{psi}$ for 20 minutes. Actively growing mycelium discs of Coriolopsis polyzona of diameter $10 \mathrm{~mm}$ were placed on each of the Triplochiton scleroxylon wooden strips after cooling. The jars and their contents were placed in an incubator at a temperature of $25^{\circ} \mathrm{C}$ and relative humidity of $70 \%$ for 4 weeks for complete colonization of the Triplochiton scleroxylon strips. Thereafter, an oven-dried sterilized specimen of the polished and unpolished particleboards were gently placed on the mycelial mat that had formed on the Triplochiton scleroxylon strips in the glass jars under sterile conditions.

The set-ups were then incubated again for 12 weeks at a temperature and relative humidity of $25^{\circ} \mathrm{C}$ and $70 \%$ respectively in order to allow the C. polyzona to feed on the particleboard specimens. At the end of the period, the specimens were removed from the glass jar, cleaned by gently removing any adhering mycelium and oven dried for 24 hours at a temperature of $103^{\circ} \mathrm{C} \pm 2^{\circ} \mathrm{C}$ until a constant weight was recorded. The percentage weight loss caused by the action of the decaying fungus was determined as shown in Equation (1):

$$
\text { Percentage weight loss }(\%)=\frac{I_{w}-F_{w}}{I_{w}} \times 100
$$

where:

$I_{W}=$ Initial oven-dry weight of specimen.

$F_{W}=$ Final oven-dry weight of specimen.

\subsection{Decay Resistance Rating of Test Specimen}

The decay resistance rating of the test specimens was based on the weight loss classification adopted from the ASTM D2017-05 [17] as indicated in Table 1.

Table 1. Decay resistance classification for percentage weight loss.

\begin{tabular}{cc}
\hline Average weight loss (\%) & Decay resistance class \\
\hline $0-10$ & Highly resistant (Class I) \\
$11-24$ & Resistant (Class II) \\
$25-44$ & Moderately resistant (Class III) \\
45 and above & Susceptible (Class IV) \\
\hline
\end{tabular}




\subsection{Decay Susceptibility Index}

Curlings and Murphy [18] proposed method for determination of decay susceptibility index (DSI) was used to determine the intensity of attack of the particleboard for the different finished surfaces, agro-forest residue type and the adhesives used. The actual mass losses of the manufactured particleboards caused by fungus Coriolopsis polyzona were compared with the mass losses of the appropriate reference timber (Terminalia superba). Based on this method the DSI for the samples were computed as shown in Equation (2):

$$
\text { Decay susceptibility index }(\%)=\frac{\text { MLs }}{\text { MLc }} \times 100
$$

where:

MLs $=$ Mass loss of the composite sample.

MLc $=$ Mass loss of the appropriate reference timber (Terminalia superba).

\subsection{Scanning Electron Micrograph Analysis of Specimen}

Scanning electron micrographs of test specimen were obtained from Phenom ProX desktop SEM with EID. Sections of the test specimens were cut into dimension $10 \mathrm{~mm} \times 10 \mathrm{~mm} \times 5 \mathrm{~mm}$; coated with a thin film of platinum to make them conductive; mounted on aluminum stub using carbon tape and then analyzed using acceleration of $15 \mathrm{kV}$ with a magnification range of $1300 \times$ to $1500 \times$.

\subsection{Statistical Analysis}

The data obtained were analysed using descriptive and inferential statistics. Statistical software used for the analyses was version 20 of Statistical Package for Social Scientists (SPSS). The mean and standard deviation of the percentage weight loss were computed and the decay resistance class determined. Tukey's multiple comparison of means was used to establish significant difference between means of decay susceptibility index at $5 \%$ level of significance.

\section{Results and Discussion}

\subsection{Surface Morphology}

The surface morphology analysis of the manufactured particleboards was carried out using scanning electron microscope (SEM) and the images obtained are as shown in Figures 2(a)-(h). The study of the surface morphology was significant in identifying the adhesive spread and the fibre arrangement in the manufactured particleboard which could influence the decay activity of the C. polyzona. The microstructure of $T$. cacao pod particleboards revealed major structure of micro cracks, pores and loose particles (Figure $2(\mathrm{~g})$ and Figure $2(\mathrm{~h})$ indicated with arrows). It was observed that the particles were detached from the adhesive. This could lead to water accumulation in such spaces thereby, creating a conducive environment for easy penetration of mycelium into the core of the specimen, thus increasing the rate of decay activity by the $C$. polyzona. 

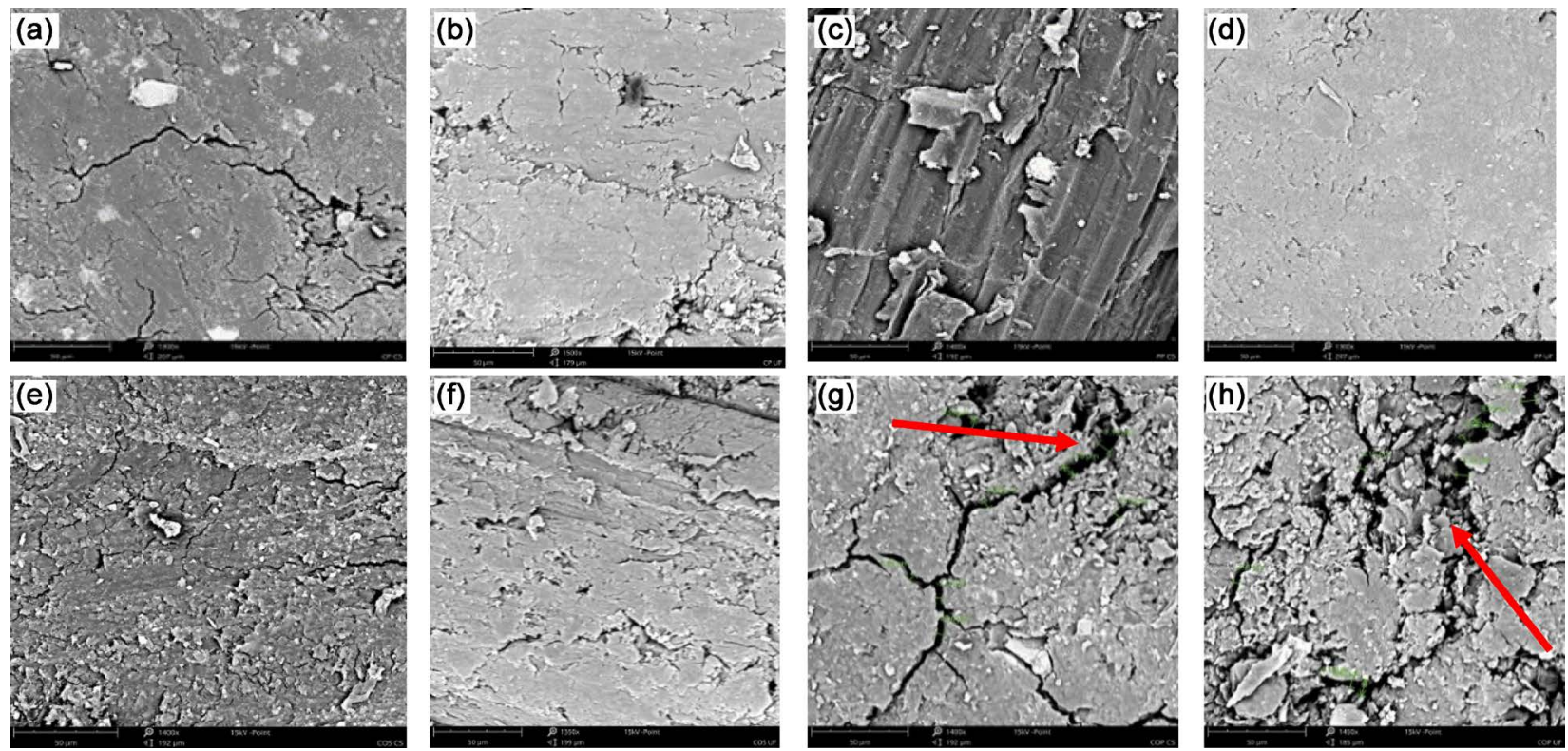

Legend: $\mathrm{CP}=$ Ceiba pentandra: $\mathrm{MPP}=$ Musa paradisiaca pseudostem: $\mathrm{TCP}=$ Theobroma cacao pod: $\mathrm{TCS}=$ Theobroma cacao stem: $\mathrm{CS}=$ Cassava starch: UF = Urea formaldehyde.

Figure 2. Scanning electron micrographs magnification range of $1300 \times$ to $1500 \times$ of the manufactured particleboards. (a) $\mathrm{CP}+$ $100 \%$ CS; (b) CP + 100\% UF; (c) MPP + 100\% CS; (d) MPP 100\% UF; (e) TCS + 100\% CS; (f) TCS + 100\% UF; (g) TCP + 100\% CS; (h) TCP + 100\% UF.

The scanning micrographs of $C$. pentandra, $M$. paradisiaca pseudostem and $T$. cacao stem particleboards show clear and smooth agglomeration of adhesives on their surfaces (Figures 2(a)-(f)) at the magnification range of $1300 \times$ to $1500 \times$. This therefore protects the surfaces against mycelium entry. This clear and smoothness of the surface of the particleboards is due to good interfacial bonding between the adhesives and the particles. Han et al. [19], Dalen, [20] and Idris et al. [21] indicated that such characteristic enhances the resistance of the particleboard to fungus invasion.

The SEM micrographs (Figure 2) indicate that the differences in the specimens were the vast display of particle-particle and particle-adhesive interactions which enhanced the bonding, thus, eliminating pores that could be exploited by C. polyzona. However, there existed micro cracks and pores (measured in average of $6.37 \mu \mathrm{m}$. at $1400 \times$ ) on the surface of the $T$. cacao pod particleboards which could be caused by its high bulk density $\left(323.96 \mathrm{~km}^{3}\right)$ and the presence of parenchyma tissues. T. cacao pod contains a higher proportion of parenchyma tissues which has greater affinity for water absorption. Ramle et al. [22] and Abdullah et al. [23] emphasized that parenchyma cells are more hygroscopic, naturally spongy and have high capacity for water absorption and storage than other cells. This provides conducive environment for active invasion by C. polyzona. The smooth surface of the particleboards manufactured from $M$. paradisiaca pseudostem, T. cacao stem and C. pentandra is an indication of good compatibility between the biomass particles and adhesives used. It was further observed that the particles were not detached from the adhesive. This might be 
due to good interfacial bonding between the adhesives and the particles as was observed by Han et al. [19] and Dalen [20]. Idris et al. [21] confirmed that this good bonding was achieved from compounding of particles and adhesives which inhibits access to $C$. polyzona, thus improving the decay resistance of the composite panel.

\subsection{Decay Resistance}

Figure 3 and Figure 4 indicate the weight loss of polished and unpolished particleboards produced from the four agro-forest residues using CS and UF as adhesives. With CS as an adhesive, the highest weight loss for the unpolished particleboards was obtained for $T$. cacao pod (46.18\%), followed by $C$. pentandra (41.43\%), T. cacao stem (22.08\%) and M. paradisiaca pseudostem (15.54\%) in that order. For the same adhesive, the polished particleboards showed a similar

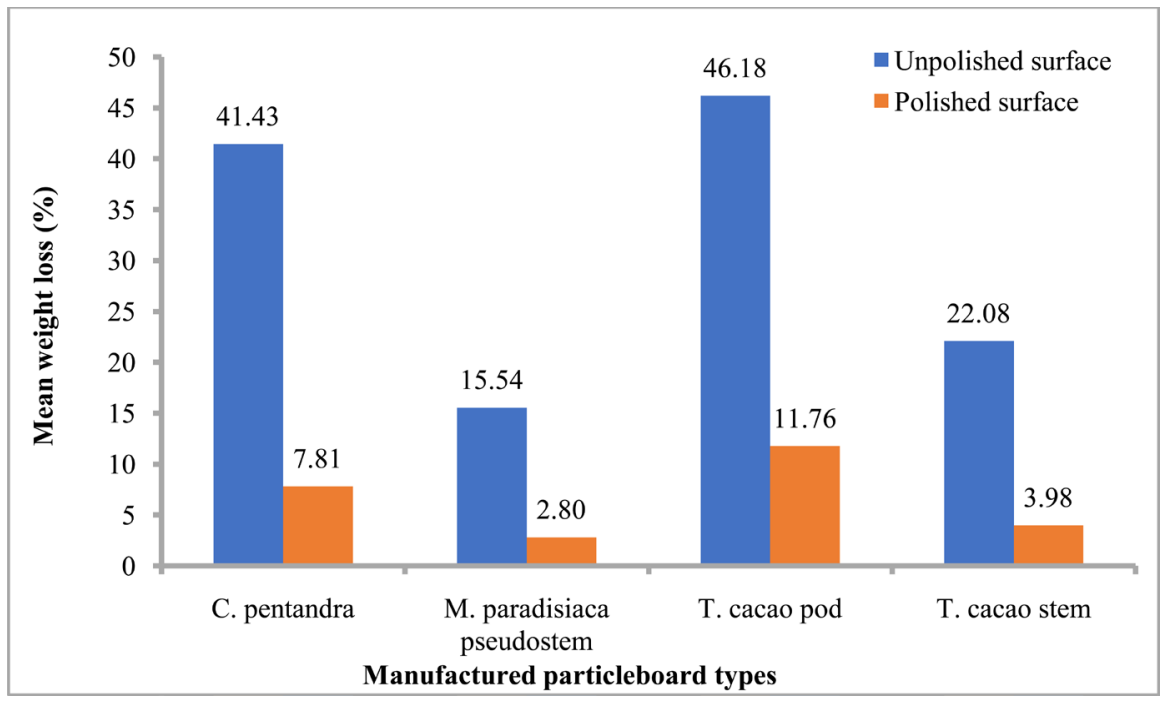

Figure 3. Weight loss of particleboards with cassava starch as adhesive.

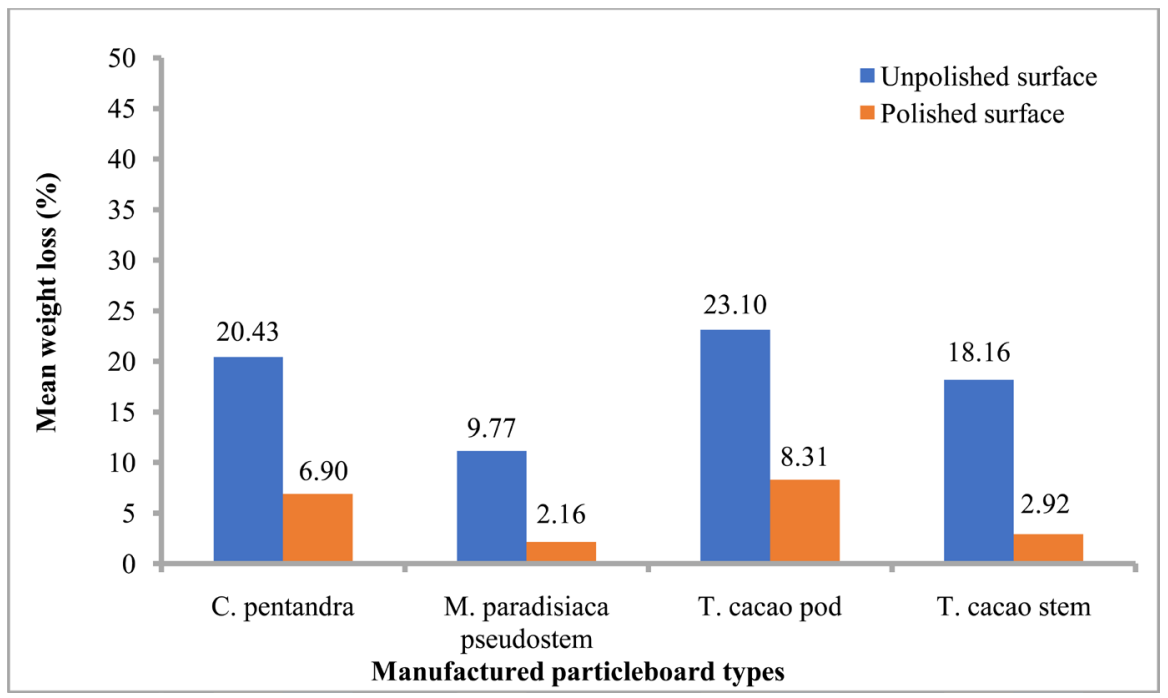

Figure 4. Weight loss of particleboards with urea formaldehyde as adhesive. 
weight loss trend. The highest weight loss was obtained for T. cacao pod particleboard (11.77\%) followed by C. pentandra (7.81\%), T. cacao stem $(3.98 \%)$ and $M$. paradisiaca pseudostem $(2.80 \%)$ in that order. Similar trend of weight loss was obtained for particleboards produced using UF (Figure 4) with $T$. cacao pod recording the highest weight loss and $M$. paradisiaca pseudostem recording the least weight loss for both the polished and unpolished surfaces. The low weight loss of M. paradisiaca pseudostem could be attributed to its higher aspect ratio (153.03) as compared to the other agro-forest residues $(T$. cacao stem $=$ 61.60; $C$. pentandra $=60.54)$ which resulted in better interlocking of the fibres to form stronger bonds. This therefore, resulted in less void space and more connected surface area (Figure 2(c) and Figure 2(d)) which inhibit fungi attack. Besides, M. paradisiaca pseudostem has high content of carbon, extractives and inorganic components which are difficult to digest by fungi [24].

The result further indicates that for the same raw material, particleboards produced using UF had weight loss far lower than their corresponding ones produced from CS. This could be attributed to the toxic preservative-chemicals found in UF meant to extend the service-life of particleboards manufactured with it [25] [26]. Therefore, using UF as an adhesive will lead to production of particleboards with better resistance to attack by $C$. polyzona than the use of CS.

Furthermore, for particleboards made from the same agro-forest residue the percentage weight loss of the polished specimens was lower than the unpolished ones. This could be due to the fact that the lacquer when applied seals the pores and produces a film of coating that protects the surface of the particleboard from C. polyzona colonization and penetration, thereby increasing its decay resistance. In addition, flavonoids, phenolic compounds and tannins in the lacquer act to improve the durability of the particleboards [27] [28] [29] [30] [31]. Similar results were indicated for the effect of varnish coating by Rafiquzzaman et al. [32], Sonmez et al. [33], Kaygin et al. [34] and Metha [35]. On the average, the weight loss of the particleboards produced was lower than the maximum value indicated by ASTM D 2017 (2005) [17] which is 50\%. This suggests that all the particleboards produced have good resistance to C. polyzona.

Table 2 which indicates the ANOVA results shows that at $5 \%$ level of significance, the agro-forest residue, adhesive used and surface finish (i.e. polished or unpolished) as well as their interactions have significant effects on the weight loss of the particleboards produced ( $\mathrm{p}$-value $<0.05$ ). The multiple coefficient of determination value $\left(\mathrm{R}^{2}\right)$ and root mean square error (RMSE) of the ANOVA model were 0.9150 and 4.2306 respectively. This suggests that about $91.50 \%$ of the variability in the weight loss of the manufactured particleboards could be explained by the agro-forest residue, the adhesives used, the surface finish and their interactions.

\subsection{Decay Resistance Rating}

The decay resistance rating of the polished and the unpolished manufactured 
particleboards are shown in Table 3. The analysis of weight loss caused by Coriolopsis polyzona indicates that the attack was intense on particleboard manufactured from $T$. cacao pod blended using CS as it is rated as being susceptible to Coriolopsis polyzona attack. All the particleboards produced from the other

Table 2. ANOVA of durability property of the manufactured particleboard.

\begin{tabular}{cccccc}
\hline Source & DF & $\begin{array}{c}\text { ANOVA } \\
\text { SS }\end{array}$ & $\begin{array}{c}\text { Mean } \\
\text { square }\end{array}$ & F-ratio & p-value \\
\hline Agro-forest residue & 3 & 3254.01 & 1084.67 & 60.60 & $0.000^{*}$ \\
$\quad$ Adhesive & 1 & 1337.44 & 1337.44 & 74.73 & $0.000^{*}$ \\
$\quad$ Surface finish & 1 & 8413.91 & 8413.91 & 470.10 & $0.000^{*}$ \\
Agro-forest residue $\times$ Adhesive & 3 & 531.51 & 177.17 & 9.90 & $0.000^{*}$ \\
$\begin{array}{c}\text { Agro-forest residue } \times \text { Surface finish } \\
\text { Adhesive } \times \text { Surface finish }\end{array}$ & 3 & 806.23 & 268.74 & 15.02 & $0.000^{*}$ \\
$\begin{array}{c}\text { Agro-forest residue } \times \text { Adhesive } \\
\times \text { Surface finish }\end{array}$ & 1 & 851.11 & 851.11 & 47.55 & $0.000^{*}$ \\
$\quad$ Error & 3 & 380.35 & 126.78 & 7.08 & $0.001^{*}$ \\
$\quad$ Total & 80 & 1431.86 & 17.90 & & \\
\hline
\end{tabular}

${ }^{*}$ Statistically significant at 0.05 level of significance; DF $=$ Degree of freedom.

Table 3. Durability ratings of manufactured particleboards.

\begin{tabular}{|c|c|c|}
\hline Particleboard type & Weight losses (\%) & Decay resistance class \\
\hline \multicolumn{3}{|l|}{ Unpolished specimen } \\
\hline C. pentandra $+\mathrm{CS}$ & $41.43(5.63)$ & Moderately resistant \\
\hline C. pentandra $+\mathrm{UF}$ & $20.43(5.61)$ & Resistant \\
\hline M. paradisiaca pseudostem + CS & $15.54(4.56)$ & Resistant \\
\hline M. paradisiaca pseudostem + UF & $9.77(2.38)$ & Highly resistant \\
\hline T. cacao pod + CS & $46.18(8.07)$ & Susceptible \\
\hline T. cacao pod + UF & $23.10(0.63)$ & Resistant \\
\hline T. cacao stem + CS & $22.08(4.96)$ & Resistant \\
\hline T. cacao stem + UF & $18.16(4.87)$ & Resistant \\
\hline \multicolumn{3}{|l|}{ Polished specimen } \\
\hline C. pentandra $+\mathrm{CS}$ & $7.81(2.07)$ & Highly resistant \\
\hline C. pentandra $+\mathrm{UF}$ & $6.90(2.69)$ & Highly resistant \\
\hline M. paradisiaca pseudostem $+\mathrm{CS}$ & $2.80(1.17)$ & Highly resistant \\
\hline M. paradisiaca pseudostem + UF & $2.16(0.83)$ & Highly resistant \\
\hline T. cacao pod + CS & $11.76(4.99)$ & Resistant \\
\hline T. cacao pod + UF & $8.31(1.51)$ & Highly resistant \\
\hline T. cacao stem + CS & $3.98(1.62)$ & Highly resistant \\
\hline T. cacao stem + UF & $2.92(0.55)$ & Highly resistant \\
\hline
\end{tabular}


agro-forest residues, polished and unpolished using both CS and UF as adhesives had decay resistance ratings ranging from moderately resistant to highly resistant. Most significantly, with the exception of particleboard produced from $T$. cacao pod using CS, all the particleboards for which the surfaces were polished were rated highly resistant.

\subsection{Decay Susceptible Index}

Decay susceptibility index (DSI) compensates for the differences stemming from panel thickness and makes it possible to establish a ranking of panels in terms of their resistance to wood decaying fungi (Fojutowski et al. [36]. The results of DSI of the particleboards produced are shown in Table 4. The DSI of $M$. paradisiaca pseudostem particleboard made with CS and UF were 53.91\% and 40.58\% respectively for the unpolished specimen and $8.77 \%$ and $8.22 \%$ respectively for the polished specimen. The worse situation was obtained for T. cacao pod particleboard using UF and CS for which the DSI was $152.64 \%$ and $100.20 \%$ respectively for the unpolished specimen, and $34.45 \%$ and $28.94 \%$ respectively for the polished specimen. This confirms the earlier result which indicates that particleboards manufactured from $M$. paradisiaca pseudostem show greater resistance to decay. Fojutowski et al. [36] and Curling and Murphy [18] indicated that manufactured particleboards with DSI value of $100 \%$ mean it has the same decay resistance as that of the wood used in the test for comparison. Also, particleboards with DSI values lower than $100 \%$ indicate more resistance to fungus attack than the wood used in the test for comparison, and finally, DSI values greater than $100 \%$ indicate particleboard with less resistance to fungus attack than the wood used in the test for comparison.

From the foregoing, it could be concluded that with the exception of unpolished particleboards produced from $C$. pentandra using CS, and the unpolished

Table 4. Decay susceptibility index of tested manufactured particleboards.

\begin{tabular}{ccccc}
\hline & \multicolumn{2}{c}{ Adhesive type (\%) } & \multicolumn{2}{c}{ Decay susceptibility index (\%) } \\
\cline { 2 - 5 } Particleboard type & $\begin{array}{c}\text { Cassava } \\
\text { starch }\end{array}$ & $\begin{array}{c}\text { Urea } \\
\text { formaldehyde }\end{array}$ & Unpolished & Polished \\
\hline C. pentandra & 100 & - & $150.15^{\mathrm{f}}$ & $29.58^{\mathrm{f}}$ \\
C. pentandra & - & 100 & $69.68^{\mathrm{d}}$ & $26.26^{\mathrm{d}}$ \\
M. paradisiacalpseudostem & 100 & - & $53.91^{\mathrm{b}}$ & $8.77^{\mathrm{a}}$ \\
M. paradisiacalpseudostem & - & 100 & $40.58^{\mathrm{a}}$ & $8.22^{\mathrm{a}}$ \\
T. cacao pod & 100 & - & $152.64^{\mathrm{f}}$ & $34.45^{\mathrm{g}}$ \\
T. cacao pod & - & 100 & $100.20^{\mathrm{e}}$ & $28.94^{\mathrm{e}}$ \\
T. cacao stem & 100 & - & $72.46^{\mathrm{d}}$ & $13.67^{\mathrm{c}}$ \\
T. cacao stem & - & 100 & $62.47^{\mathrm{c}}$ & $10.17^{\mathrm{b}}$ \\
\hline
\end{tabular}

Figures in columns with the same letters are not significantly different (Turkey's multiple test, p >0.05). 
ones produced from $T$. cacao pod using both CS and UF, all the other specimens used in the test were more resistant to the attack of $C$. polyzona than Terminalia superba.

\section{Conclusion}

The study investigated the decay resistance of particleboards produced from four agro-forest residues using cassava starch and urea formaldehyde as adhesives. It could be concluded that of all the four agro-forest residues used, $M$. paradisiaca pseudostem particleboard exhibited the best decay resistance characteristics against fungi attack for both urea formaldehyde and cassava starch adhesives. Additionally, particleboards produced using urea formaldehyde as an adhesive have better decay resistance properties than that of cassava starch. The above notwithstanding, almost all the particleboards produced were classified as being resistant or highly resistant to fungi attack. Therefore, cassava starch could be used as a substitute to urea formaldehyde in particleboard production. The study further concludes that particleboards coated with synthetic polyvinyl lacquer could have better resistant to fungi attack than the uncoated ones. This is due to the lacquer's ability to seal the pores and produce a coating film that protects the surface from fungi colonization and penetration in addition to flavonoids, phenolic compounds and tannins in the lacquer that improves durability. The implication is that if particleboards are coated with the appropriate finishes, they could prolong their service life. At $5 \%$ level of significance, the agro-forest residue, adhesive and surface finish as well as their interactions had significant effects on the decay resistance of the particleboards produced.

\section{Acknowledgements}

The authors are grateful to the Pathology Division of CSIR-Forestry Research Institute of Ghana for making their Pathology laboratory available for this study. We are also grateful to Mr. Emmanuel Duodu Nyarko and Miss Margaret Adablah of CSIR-FORIG for their support in the preparation of the samples for this study. Final appreciation goes to Ms. Dora Fianyo of the Department of Earth Science, University of Ghana, for her immense support during the SEM analysis.

\section{Conflicts of Interest}

The authors declare no conflicts of interest regarding the publication of this paper.

\section{References}

[1] Ayrilmis, N., Kwon, J.H. and Han, T.H. (2012) Effect of Resin Type and Content on Properties of Composite Particleboard Made of a Mixture of Wood and Rice Husk. International Journal of Adhesion and Adhesives, 38, 79-83. https://doi.org/10.1016/j.ijadhadh.2012.04.008

[2] Ashoria, A. and Nourbakhsh, A. (2008) Effect of Press Cycle Time and Resin Content on Physical and Mechanical Properties of Particleboard Panels Made from the 
Underutilized Low-Quality Raw Materials. Industrial Crops Products, 28, 225-230. https://doi.org/10.1016/j.indcrop.2008.02.015

[3] Kord, B., Zare, H. and Abdollah, H.A. (2016) Evaluation of the Mechanical and Physical Properties of Particleboard Manufactured from Canola (Brassica napus) Straws. Maderas Ciencia y Tecnología, 18, 9-18. https://doi.org/10.4067/S0718-221X2016005000002

[4] Banton, M., Shone, N., Hurst, W. and Shi, Q. (2019) A Fresh Look at Combining Logs and Network Data to Detect Anomalous Activity. 2019 International Conference on Information and Communication Technologies for Disaster Management, Paris, 18-20 December 2019, 1-6. https://doi.org/10.1109/ICT-DM47966.2019.9032959

[5] Atoyebi, O.D., Osueke, C.O., Badiru, S., Gana, A.J., Ikpotokin, I., Modupe, A.E. and Tegene, G.A. (2019) Evaluation of Particleboard from Sugarcane Bagasse and Corn Cob. International Journal of Mechanical Engineering and Technology, 10, 1193-1200.

[6] Ciannamea, E.M., Marin, D.C., Ruseckaite, R.A. and Stefani, P.M. (2017) Particleboard Based on Rice Husk: Effect of Binder Content and Processing Conditions. Journal of Renewable Materials, 5, 357-362. https://doi.org/10.7569/JRM.2017.634125

[7] Okai, R., Andoh, E.O., Mitchual, S.J. and Dzakpasu, R.K. (2015) Production of Wood Products from Particleboards Manufactured from Agricultural Residues. International Journal of Emerging Technology and Advance Engineering, 5, 30-38. http://www.ijetae.com

[8] Varanda, L.D., Christoforo, A.L., Almeida, D.H., Silva, D.A.L., Panzera, T.H. and Lahi, A.R. (2014) Evaluation of Modulus of Elasticity in Static Bending of Particleboards Manufactured with Eucalyptus grandis Wood and Oat Hulls. Acta Scientiarum Technology Maringá, 36, 405-411. https://doi.org/10.4025/actascitechnol.v36i3.21077

[9] FAO, IFAD, UNICEF, WFP and WHO (2017) The State of Food Security and Nutrition in the World 2017. Building Resilience for Peace and Food Security. FAO, Rome. http://www.fao.org/3/a-i7695e.pdf

[10] FAO (Food and Agriculture Organization) (2010) Food and Agriculture Indicators. ESSA.

[11] Dzomeku, B.M., Dankyi, A.A. and Darkey, S.K. (2011) Socioeconomic Importance of Plantain Cultivation in Ghana. Journal of Animal and Plant Sciences, 21, 269-273.

https://www.researchgate.net/publication/291500285_Socioeconomic_importance_ of_plantain_cultivation_in_Ghana

[12] Daily Graphic (2018) Overage Cocoa Trees to Go. Ngnenbe Timothy Reports, Tuesday, August 21.

[13] Cruz, G., Pirilä, M., Huuhtanen, M., Carrión, L., Alvarenga, E. and Keiski, R.L. (2012) Production of Activated Carbon from Cocoa (Theobroma cacao pod). Journal of Civil and Environmental Engineering, 2, 109. https://doi.org/10.4172/2165-784X.1000109

[14] ICCO (2018) Quarterly Bulletin of Cocoa Statistics, 44(1), Cocoa Year 2017/18, London.

[15] Paulrud, S. (2002) Particle and Handling Characteristics of Wood Fuel Powder: Effect of Different Mills. Fuel Processing Technology, 76, 23-39. https://doi.org/10.1016/S0378-3820(02)00008-5

[16] Mitchual, S.J. (2015) Enhancing the Physical Properties of Briquettes from Sawdust 
of Piptadenia africana Through Combination with Ceiba pentandra. British Journal of Applied Science and Technology, 6, 399-407. https://doi.org/10.9734/BJAST/2015/12315

[17] ASTM International: Standard Test Methods of Evaluating Properties of Wood-Base Fiber and Particle Panel Materials. ASTM D-2017 (2005) In: Annual Book of ASTM Standard. Philadelphia, 337-341.

[18] Curling, S.F. and Murphy, R.J. (2002) The Use of the Decay Susceptibility Index (DSI) in the Evaluation of Biological Durability Tests of Wood-Based Board Materials. European Journal of Wood and Wood Products, 60, 224-226. https://doi.org/10.1007/s00107-002-0284-2

[19] Han, G., Zhang, C., Zhang, D., Umerra, D. and Kawai, S. (1998) Upgrading of Urea Formaldehyde Bonded Reed and Wheat Straw Particleboard Using Silane Coupling Agents. Journal of Wood Science, 44, 282-286. https://doi.org/10.1007/BF00581308

[20] Dalen, H. (1999) Factors to Take into Consideration When Producing Particleboard from Straw. Proceedings of the Meeting of the Eastern Canadian Section of the Forest Products Society, Winnipeg, 19-20 May 1999, 456-462.

[21] Idris, U.D., Aigbodion, V.S., Gadzama, R.M. and Abdullahi, J. (2011) Eco-Friendly (Watermelon Peels) Alternatives to Wood-Based Particleboard Composite. The Pacific Journal of Science and Technology, 12, 112-117.

[22] Ramle, S.F.M., Sulaiman, O., Hashim, R., Arai, T., Kosugi, A., Abe, H., Murata, Y. and Mori, Y. (2012) Characterization of Parenchyma and Vascular Bundle of Oil Palm Trunk as Function of Storage Time. Lignocel, 1, 33-44.

[23] Abdullah, C.K., Jawaid, M., Abdul-Khalil, H.P.S., Zaidon, A. and Hadiyane, A. (2012) Oil Palm Trunk Polymer Composite: Morphology, Water Absorption and Thickness Swelling Behaviors. Bioresource, 7, 2948-2959.

[24] Melo, R.R. (2009) Physical-Mechanical Properties and Decay Resistance of Wood and Rice Husk Particleboard in Different Proportions. Master's Thesis, Federal University of Santa Maria, Santa Maria. (In Portuguese)

[25] Antwi-Boasiako, C. and Appiah, J.K. (2017) Glue-line Durability of OrganoChemical/Urea Formaldehyde Resin Joints of Ceiba pentandra Plywood. Journal of the Indian Academy of Wood Science, 14, 49-59.

https://doi.org/10.1007/s13196-017-0187-9

[26] Iswanto, A.H., Supriyanto, F.W. and Susilowati, A. (2018) Effect of Particle Treatment and Adhesive Type on Physical, Mechanical, and Durability Properties of Particleboard Made from Sorghum Bagasse. IOP Conf. Series. Earth and Environmental Science, 126, Article ID: 012016. https://doi.org/10.1088/1755-1315/126/1/012016

[27] Ya, C., Gaffney, S.H., Lilley, T.H. and Haslam, E. (1998) Chemistry and Significance of Condensed Tannins. In: Hemmingway, R.W. and Karchesy, J.J., Eds., Chemistry and Significance of Condensed Tannins, Plenum Press, New York, 553.

[28] Tsuchiya, H., Sato, M., Miyazaki, T., Fujiwara, S., Tanigaki, S., Ohyama, M., Tanaka, T. and Linuma, M. (1996) A Prenylated Flavanone from Roots of Amorpha fruticosa. Journal of Ethnopharmacol, 50, 27.

[29] Bisanda, E.T.N., Ogola, W.O. and Tesha, J.V. (2003) Characterization of Tannin Resin Blends for Particleboard Applications. Cement and Concrete Composites, 25, 593-598. https://doi.org/10.1016/S0958-9465(02)00072-0

[30] Kim, S. and Kim, H.J. (2004) Evaluation of Formaldehyde Emission of Pine and Wattle Tannin-Based Adhesives by Gas Chromatography. Holz Roh Werkst, 62, 101-106. https://doi.org/10.1007/s00107-003-0441-2 
[31] Paridah, M.T. and Musgrave, O.C. (2006) Alkaline Treatment of Sulfited Tannin-Based Adhesive from Mangrove to Increase Bond Integrity of Beech Slips. Journal of Tropical Forest Science, 18, 137-143.

[32] Rafiquzzaman, M., Rahman, M., Hossain, M. and Hasan, A. (2006) Studies on the Preparation of Oleo-Resinous Wood Varnishes by Utilizing Safflower (Carthamus tinctorius) Seed Oil. Bangladesh Journal of Scientific and Industrial Research, 41, 77-82. https://doi.org/10.3329/bjsir.v41i1.273

[33] Sonmez, A., Budakci, M. and Bayram, M. (2009) Effect of Wood Moisture Content on Adhesion of Varnish Coatings. Scientific Research and Essay, 4, 1432-1437.

[34] Kaygin, B. and Akgun, E. (2009) A Nano-Technological Product: An Innovative Varnish Type for Wooden Surfaces. Scientific Research and Essay, 4, 1-7.

[35] Metha, K.V. (2016) Varnishes, Component, Classification, Application and Literature. GRIN Verlag, Munich, Textbook, 59. https://www.grin.com/document/339031

[36] Fojutowski, A., Kropacz, A. and Noskowiak, A. (2009) Determination of WoodBased Panels' Resistance to Wood Attacking Fungi. Folia Forestalia Polonica, Series $B, 40,79-88$.

https://ffp.matlibhax.com/pdf/40/Folia\%20Forestalia\%20Pol\%2040-9\%20Fojutowsk i\%20et\%20al.pdf 